\title{
The economic viability of the inclusion of urea in the ration for feedlot lambs
}

\author{
Viabilidade econômica da inclusão de ureia na ração para cordeiros confinados
}

\section{ROZANSKI, Sandra ${ }^{1}$; VIVIAN, Diana Rosana ${ }^{1}$; KOWALSKI, Luciana Helena ${ }^{1}$; ROCHADELLI, Roberto ${ }^{2}$; FREITAS, José Antônio de ${ }^{3}$; GARCEZ NETO, Américo Fróes ${ }^{3}$; FERNANDES, Sergio Rodrigo ${ }^{4 *}$}

\footnotetext{
${ }^{1}$ Mestre em Ciência Animal pela Universidade Federal do Paraná (UFPR), Palotina, Paraná, Brasil;

${ }^{2}$ Departamento de Sociais e Humanas, UFPR, Palotina, Paraná, Brasil;

${ }^{3}$ Departamento de Zootecnia, UFPR, Palotina, Paraná, Brasil;

${ }^{4}$ Programa de Pós-graduação em Ciência Animal (PPGCA), UFPR, Palotina, Paraná, Brasil.

*Corresponding author: e-mail: srfernandes83@gmail.com-Universidade Federal do Paraná Zootecnia, Rua Pioneiro, 2153, Jd. Dallas , Palotina, Paraná 85950000, Brazil.

\section{SUMMARY}

The aim of this study was to evaluate the economic viability of the inclusion of urea in the ration provided to feedlot lambs. Twenty-four non-castrated male lambs, crossbred Dorper, with 2-5 months of age and a body weight $(\mathrm{BW})$ of $25.0 \pm 4.3 \mathrm{~kg}$ were used. A completely randomized design with four treatments and six replicates was adopted, in which the treatments were urea levels of $0.0,0.5,1.0$ and $1.5 \%$ in the ration, on a dry matter (DM) basis. Lambs were fed ad libitum for 56 days and slaughtered at a BW of $37.9 \pm$ $5.1 \mathrm{~kg}$. The analyzed economic indexes were the cost of the rations, cost of marginal factor (CMF), revenue of marginal factor (RMF), net revenue (NR) and benefit: cost ratio (BCR). The ration without urea presented the highest cost $(0.30 \mathrm{US} \$ / \mathrm{kg} \mathrm{DM})$ and the ration with $1.0 \% \mathrm{DM}$ of urea had the lowest cost $(0.23$ US $\$ / k g$ DM). The CMF had a quadratic response to the urea level, reaching the lowest value (0.28 US\$/day) with the addition of 0.9 to $1.0 \%$ DM of urea. The lowest and the highest NR values were obtained from the rations without and with $1.5 \% \mathrm{DM}$ of urea, respectively $(0.26$ and $0.34 \mathrm{US} \$$ /day). The ration without urea had a worse BCR (1.74), whereas the ration with $1.0 \% \mathrm{DM}$ of urea resulted in a better BCR (2.09). A better economic return for lambs finishing in feedlots is obtained with rations containing 1.0 to $1.5 \% \mathrm{DM}$ of urea.

Keywords: benefit: cost ratio, concentrate feed, economic return, net revenue, nonprotein nitrogen

\section{RESUMO}

Objetivou-se com este estudo avaliar a viabilidade econômica da inclusão de ureia na ração fornecida para cordeiros terminados em confinamento. Foram utilizados 24 cordeiros machos não castrados, mestiços Dorper, com 2 a 5 meses de idade e $25,0 \pm 4,3 \mathrm{~kg}$ de peso corporal (PC). $\mathrm{O}$ delineamento experimental foi inteiramente casualizado com quatro tratamentos e seis repetições, onde os tratamentos foram os teores de 0,0 ; 0,$5 ; 1,0$ e $1,5 \%$ de ureia na ração, com base na matéria seca (MS). Os cordeiros foram alimentados ad libitum por 56 dias $\mathrm{e}$ abatidos com 37,9 $\pm 5,1 \mathrm{~kg}$ de PC. Os índices econômicos analisados foram custo das rações, custo do fator marginal (CFM), receita do fator marginal (RFM), receita líquida (RL) e relação benefício:custo (RBC). A ração sem ureia apresentou o 
maior custo $(0,30 \mathrm{US} \$ / \mathrm{kg} \mathrm{MS})$ e a ração com $1,0 \%$ MS de ureia teve o menor custo $(0,23 \mathrm{US} \$ / \mathrm{kg}$ MS). O CFM apresentou resposta quadrática aos níveis de ureia, alcançando o menor valor $(0,28$ US $\$ /$ dia $)$ com a inclusão de 0,9 a 1,0\% MS de ureia na ração. $\mathrm{O}$ menor e o maior valor de RL foram obtidos a partir das rações sem e com $1,5 \%$ MS de ureia, respectivamente $(0,26 \mathrm{e}$ 0,34 US\$/dia). A ração sem ureia apresentou a pior $\operatorname{RBC}(1,74)$, enquanto a ração com $1,0 \%$ MS de ureia resultou na melhor $\operatorname{RBC}(2,09)$. O melhor retorno econômico na terminação de cordeiros em confinamento é obtido com rações contendo 1,0 a $1,5 \%$ MS de ureia.

Palavras-chave: concentrado, nitrogênio não-proteico, receita líquida, relação benefício:custo, retorno econômico 


\section{INTRODUCTION}

The efficiency of transforming feed into meat and the cost of production are key factors in lamb production systems, and must be considered for carcass and meat commercialization (Salinas-Chavira et al., 2007). In this context, feedlots area powerful tool for meat production in a relatively short period compared to other production strategies, providing standardized and high quality carcasses and a fast return on invested capital (Vieira et al., 2012). However, feeding may represent up to $70 \%$ of the total variable cost of production, in which the protein ingredients are the most expensive components of the ration (Barros et al., 2009). Regarding the importance of these ingredients for the feeding of feedlot lambs, the cost of the produced carcass may be affected by the amount and the source of protein added to the ration (Zundt et al., 2002).

The high cost of conventional protein sources, as well as the lack of protein feedstuffs in many regions of the world, has stimulated studies of the use of alternative sources (Burque et al., 2008), targeting positive economic and performance indexes (Faria et al., 2011). In this scenario, urea is a nonprotein nitrogen (NPN) source that can partially replace ruminal degradable protein (RDP) sources, and may be used on a large scale to reduce feeding costs in feedlots(Vidal et al., 2004; Burque et al., 2008; Khattab et al., 2013). Since urea has a high protein equivalent, the low inclusion of this source can replace a high amount of RDP sources, which are more expensive (Gerassev et al., 2013).

To assess the effectiveness of the use of alternative feedstuffs, some production and economic indexes that represent the productive and financial reality of the activity should be measured; among the production indexes, the intake and digestibility of dry matter (DM) and nutrients, feed conversion ratio (FCR), average daily gain (ADG) and carcass yield stand out (Pereira et al., 2008; Soares et al., 2015). This study aimed to evaluate the economic viability of the inclusion of urea in the ration for feedlot lambs.

\section{MATERIAL AND METHODS}

The trial and procedures carried out on the animals were in accordance with the Ethical Principles in Animal Experimentation adopted by the Brazilian College of Animal Experimentation (Colégio Brasileiro de Experimentação Animal - COBEA) and were approved by the Animal Care and Use Committee (Comissão de Ética no Uso de Animais - CEUA) of the Federal University of Paraná (Universidade Federal do Paraná - UFPR), Palotina Campus, under protocol number 08/2012-CEUA issued by the Committee.

The trial was carried out at the Small Ruminants Studies Center (Centro de Estudos em Pequenos Ruminantes CEPER) of UFPR, Palotina Campus, located in Palotina, Paraná state, Brazil. Twenty-four non-castrated male lambs, crossbred Dorper, with 2-5 months of age and a body weight (BW) of $25.0 \pm$ $4.3 \mathrm{~kg}$ (mean \pm standard deviation $\mathrm{SD})$ were used.At the start of the trial, the lambs were weighed, identified with ear tags and dewormed (Ivermectin at a dose of $1 \mathrm{~mL} / 50 \quad \mathrm{~kg} \quad \mathrm{BW}$ subcutaneously). Subsequently, the lambs were housed in individual pens on a covered slatted floor. The pens had an area of $1.5 \mathrm{~m}^{2}$ and contained a water drinker and individual trough for the ration. 
The design was completely randomized with four treatments and six replicates, where the treatments were the inclusion of $0.0,0.5,1.0$ and $1.5 \%$ urea in the ration, based on DM. Rations were composed of $34 \%$ DM of Tifton 85 hay (Cynodon spp.) and 66\% DM of protein-energy concentrate, on average (Table 1), and formulated to meet the requirements for moderate weight gain (16.7\% DM of crude protein - CP; 2.40 $\mathrm{Mcal} / \mathrm{kg} \mathrm{DM}$ of metabolizable energy -
ME; 200 g/day of average daily gain ADG; NRC, 1985). The CP content among the ingredients of the rations was $16.0 \%$ for Tifton 85 hay, $18.0 \%$ for commercial pelleted concentrate, $12.6 \%$ for soybean hulls, $7.4 \%$ for ground corn and $281 \%$ for conventional urea (protein equivalent), on a DM basis. Hay was shredded into particles approximately $3 \mathrm{~cm}$ long to improve utilization by the lambs and reduce waste in the trough.

Table 1. Ingredients, dry matter, protein and energy contents of the experimental rations, and the cost of the feedstuffs used to prepare the rations

\begin{tabular}{|c|c|c|c|c|c|}
\hline \multirow{2}{*}{ Composition $^{\mathrm{I}}$} & \multicolumn{4}{|c|}{ Urea $(\% \mathrm{DM})^{\mathrm{I}}$} & \multirow{2}{*}{ Cost $^{\mathrm{II}}$} \\
\hline & 0.0 & 0.5 & 1.0 & 1.5 & \\
\hline Tifton 85 hay (\% DM) & 36.0 & 40.0 & 34.0 & 25.0 & 0.18 \\
\hline Concentrate feed (\% DM) & 64.0 & 60.0 & 66.0 & 75.0 & - \\
\hline CPC (\% DM) & 58.0 & 33.5 & 15.0 & 26.0 & 0.38 \\
\hline Soybean hulls (\% DM) & 5.0 & 25.0 & 49.0 & 19.0 & 0.21 \\
\hline Ground corn (\% DM) & 0.0 & 0.0 & 0.0 & 27.5 & 0.31 \\
\hline Mineral premix (\% DM) & 1.0 & 1.0 & 1.0 & 1.0 & 0.66 \\
\hline Urea $(\% \mathrm{DM})$ & 0.0 & 0.5 & 1.0 & 1.5 & 0.38 \\
\hline $\mathrm{DM}(\%)$ & 86.7 & 87.9 & 89.5 & 88.5 & - \\
\hline $\mathrm{CP}(\% \mathrm{DM})$ & 16.9 & 17.0 & 17.2 & 17.1 & - \\
\hline $\mathrm{ME}(\mathrm{Mcal} / \mathrm{kg} \mathrm{DM})$ & 2.35 & 2.27 & 2.27 & 2.48 & - \\
\hline
\end{tabular}

The period of adaptation to the experimental management was 15 days and the trial period was 56 days. The rations were supplied as total mixed ration (TMR) and split into two daily meals (8h00 and 14h00). The lambs were fed ad libitum during the adaptation period and the trial, with the leftovers kept at $10 \%$ of the amount of feed provided. Adjustments to the amount of ration supplied were performed every 5days based on the amount of food refused.

Lambs were weighed after 12 hours of fasting on the first and the last day of the trial to calculate the ADG. The daily dry matter intake (DMI) was calculated as the difference between the amount of $\mathrm{DM}$ in the feed provided and in the leftovers. The DMI relative to $\mathrm{BW}$ $\left(\mathrm{DMI}_{\mathrm{BW}}\right)$ was calculated by dividing the mean DMI by the mean lamb BW 
during the trial, as reported by Vivian et al. (2017).

Lambs were slaughtered at the end of the trial, with an average BW of $37.9 \pm$ $5.1 \mathrm{~kg}$ (mean $\pm \mathrm{SD}$ ). Upon reaching this BW, lambs were fasted (feed was withdrawn for 16 hours), weighed to record the body weight at slaughter (SW) and sent to a commercial slaughterhouse in the region. The slaughter was conducted in accordance with good animal welfare practices, in which the animals were stunned, followed by bleeding (performed by severing the jugular veins and carotid arteries), skinning and evisceration. After slaughter, the carcasses were identified, suspended by the metatarsal joints and transferred to a cold room at $4^{\circ} \mathrm{C}$, where they remained for 24 hours .Post-cooling, carcasses were weighed to record the cold carcass weight (CCW), and the commercial or cold carcass yield (CCY) was calculated as follows: $\quad C C Y=(C C W / S W) \times$ 100.The carcass trait results were reported by Rozanski et al. (2017). The previously described performance and carcass traits were the production indexes considered in the economic analysis; they are summarized in Table 2 .

Table 2. Production indexes used in the calculation of the financial indicators of the experimental rations

\begin{tabular}{|c|c|c|c|c|}
\hline \multirow{2}{*}{ Production index ${ }^{\mathrm{I}}$} & \multicolumn{4}{|c|}{ Urea $(\% \mathrm{DM})^{\mathrm{I}}$} \\
\hline & 0.0 & 0.5 & 1.0 & 1.5 \\
\hline IBW (kg) & 25.07 & 24.96 & 25.93 & 24.10 \\
\hline $\mathrm{SW}^{\mathrm{II}}(\mathrm{kg})$ & 37.67 & 38.08 & 38.00 & 37.73 \\
\hline ADG (kg/day) & 0.225 & 0.234 & 0.215 & 0.243 \\
\hline DMI (kg/day) & 1.215 & 1.178 & 1.233 & 1.159 \\
\hline $\mathrm{DMI}_{\mathrm{BW}}{ }^{\mathrm{III}}$ (\% BW/day) & 3.90 & 3.77 & 3.87 & 3.77 \\
\hline $\mathrm{CCW}^{\mathrm{II}}(\mathrm{kg})$ & 16.93 & 16.67 & 17.13 & 17.01 \\
\hline $\mathrm{CCY}^{\mathrm{II}}(\%)$ & 44.83 & 43.54 & 45.03 & 45.09 \\
\hline
\end{tabular}

I DM: dry matter; IBW: initial body weight; SW: slaughter weight; ADG: average daily gain; DMI: dry matter intake; $\mathrm{DMI}_{\mathrm{BW}}$ : dry matter intake relative to body weight; $\mathrm{CCW}$ : cold carcass weight; CCY: cold carcass yield

${ }^{\mathrm{II}}$ Reported by Rozanski et al. (2017)

III Reported by Vivian et al. (2017)

The economic analysis was performed based on the DMI and ADG to verify the feasibility of the use of rations without considering the other fixed and operational costs, since these were the same for the four treatments. The cost of feedstuffs(Table 1) and the marketing value of cold carcasses were obtained during the two first weeks of November, 2014 in the western region of Paraná state. The mean marketing value of a carcass (VC) was 6.11 US\$ per kilogram.

Production indexes and financial indicators were used in the calculation of the economic indexes to assess 
economic viability according to Hoffmann et al. (1989). The following indexes were calculated: (1) cost of rations $(\mathrm{CR})$ - calculated from the costs of feedstuffs on a DM basis and their proportions in each ration(Table 1); (2) cost of marginal factor (CMF) calculated by the formula $C M F=$ $D M I \times C R$, and represented by the daily cost of production with each ration; (3) revenue of marginal factor (RMF) calculated by the formula $R M F=$ $(A D G \times C C Y) \times V C$, and represented by the daily income from carcass production; (4) net revenue (NR) calculated by the subtraction of $\mathrm{CMF}$ from RMF, and represented by the net value obtained from a carcass sale; (5) benefit: cost ratio (BCR) - obtained by the division between RMF and CMF, and indicated by the return of capital for each monetary unit applied. The CMF, RMF, NR and BCR were calculated for each replicate (lamb) and compared between the four rations.

To evaluate the behavior of the economic indexes with the increasing levels of urea in the ration, the data were analyzed using a regression (PROC REG), up to a second order (quadratic), with urea level as an independent variable. However, due to the great impact of the economic indexes on the farmers'profitability, the interpretation of the results was performed based on the numerical differences between the values obtained for each ration from the economic analysis. Regression analysis was performed using the Statistical Analysis System, version 9.0 (SAS, 2002), with a significance level of 0.05 . The economic analysis was carried out using spreadsheets in Microsoft Excel ${ }^{\circledR} 2010$.

\section{RESULTS AND DISCUSSION}

As reported by Vivian et al. (2017) and Rozanski et al. (2017), DMI, ADG, SW, CCW and CCY (Table 2) were not affected by the inclusion of urea in the ration, which demonstrated that levels of urea ranging from 0.0 to $1.5 \% \mathrm{DM}$ provide the same productive response in crossbred Dorper lambs finished in a feedlot.

Regarding the CR, the minimum and maximum costs were verified in the rations with $1.0 \% \mathrm{DM}$ of urea and without urea, respectively $(0.23$ and $0.30 \mathrm{US} \$ / \mathrm{kg}$ DM, respectively; Table 3). These results differ from other studies, which have shown that increasing the urea content in the ration reduces the feeding cost (Musalia et al., 2000; Souza et al., 2004). Although this pattern was not observed in the present study, the rations with urea had lower costs than the ration without urea. This occurred because urea has a great protein equivalent and a low cost relative to RDP (US\$/kg of protein), supporting its use in the feed provided in feedlots (Souza et al., 2004). Moreover, the higher addition of soybean hulls in the rations with urea contributed to reducing the $\mathrm{CR}$, since this ingredient had the lowest cost $(0.21$ US\$/kg DM) among the feedstuffs added to the concentrate feed (Table 1). Santos et al. (2008) also observed a reduction of the $\mathrm{CR}$ with the replacement of ground corn by soybean hulls. 
Table 3. Means and standard errors of the means (SEM) for the economic indexes of rations with increasing levels of urea, provided to crossbred Dorper lambs in the growing and finishing phases

\begin{tabular}{|c|c|c|c|c|c|c|c|}
\hline \multirow{2}{*}{$\begin{array}{c}\text { Economic } \\
\text { index }^{I}\end{array}$} & \multicolumn{4}{|c|}{ Urea $(\% \mathrm{DM})^{\mathrm{I}}$} & \multirow{2}{*}{ SEM } & \multicolumn{2}{|c|}{$P$-value ${ }^{\mathrm{II}}$} \\
\hline & 0.0 & 0.5 & 1.0 & 1.5 & & Lin & Quad \\
\hline $\mathrm{CR}(\mathrm{US} \$ / \mathrm{kg} \mathrm{DM})$ & 0.30 & 0.26 & 0.23 & 0.28 & - & - & - \\
\hline CMF(US\$/day) & 0.36 & 0.30 & 0.28 & 0.33 & 0.01 & 0.1776 & 0.0115 \\
\hline RMF (US\$/day) & 0.62 & 0.62 & 0.59 & 0.67 & 0.03 & 0.5948 & 0.4897 \\
\hline NR (US\$/day) & 0.26 & 0.32 & 0.31 & 0.34 & 0.02 & 0.2349 & 0.7749 \\
\hline BCR & 1.74 & 2.08 & 2.09 & 2.05 & 0.08 & 0.1531 & 0.2104 \\
\hline
\end{tabular}

${ }^{\mathrm{I}} \mathrm{DM}$ : dry matter; CR: cost of ration; CMF: cost of marginal factor; RMF: revenue of marginal factor; NR: net revenue; BCR: benefit: cost ratio

${ }^{\mathrm{II}}$ Lin: linear regression; Quad: quadratic regression

The CMF was lower in the rations with urea compared to the ration without urea, and showed a quadratic response $(\mathrm{P}<0.05)$ with increasing urea levels (Table 3). According to the regression equation, the minimum CMF (0.28 US\$/day) could be reached with the inclusion of 0.9 to $1.0 \% \mathrm{DM}$ of urea in the ration (Figure 1).The minimum estimated CMF was slightly higher than that verified by Rocha et al. (2016), who noted values of 0.25 US\$/day for crossbred Dorper lambs that showed similar performance traits (initial and final $\mathrm{BW}, \mathrm{DMI}$ and $\mathrm{ADG}$ ) to the lambs used in the present study, and were fed ration with a roughage: concentrate ratio of 35:65. These authors used a ration composed of $35.0 \%$ maniçoba hay, $37.0 \%$ ground corn, $19.0 \%$ soybean meal, $5.5 \%$ wheat meal, $2.0 \%$ soybean oil, $0.5 \%$ mineral supplement and $1.0 \%$ limestone, on a DM basis; the roughage: concentrate ratio of this ration was similar to the ration with $1.0 \%$ DM of urea (34:66; Table 1), and the higher CMF observed in the present study is probably associated with the high cost of the commercial pelleted concentrate added to the rations. The CMF represents the daily cost of carcass production, and was lower for the ration with $1.0 \% \mathrm{DM}$ of urea as a consequence of its low CR. 


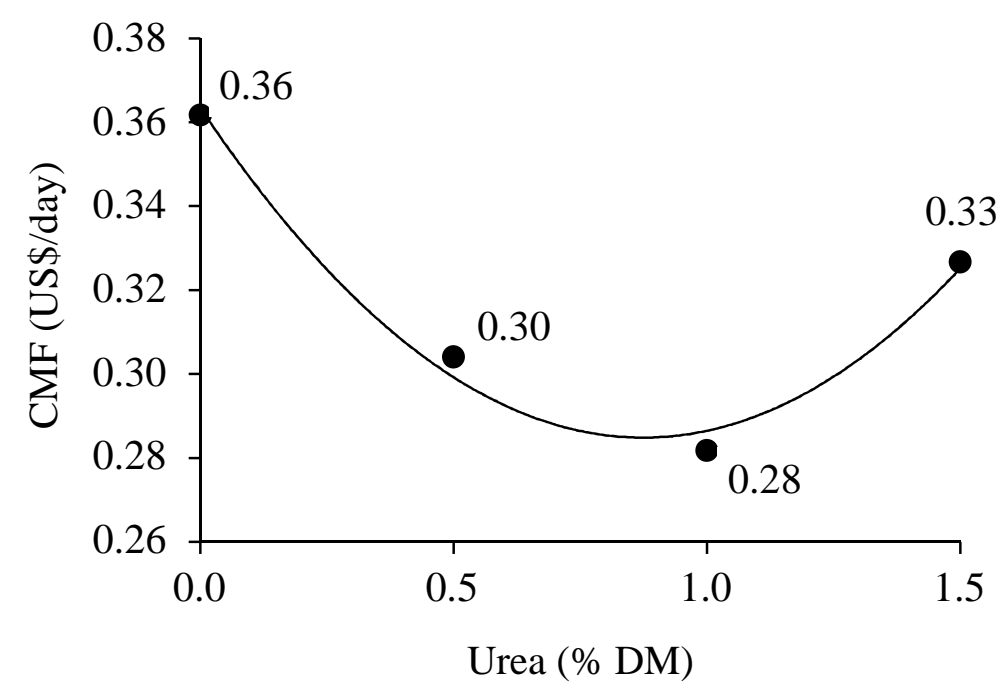

Figure 1. Cost of marginal factor (CMF) from rations with increasing levels of urea (\% of dry matter - DM), provided to crossbred Dorper lambs in the growing and finishing phases

Regression equation: $C M F=0.3631-0.1806 U+0.1035 U^{2}\left(R^{2}=0.985\right)$

The RMF did not present a linear or quadratic response $(\mathrm{P}>0.05)$ to the inclusion of urea in the ration, with minimum and maximum values for the rations with 1.0 and $1.5 \% \mathrm{DM}$ of urea, respectively ( 0.59 and 0.67 US $\$ /$ day; Table 3). This difference is related to the lambs' ADG, which did not differ statistically between the urea levels (Vivian et al., 2017), but had a greater value in the ration with $1.5 \% \mathrm{DM}$ of urea $(0.243 \mathrm{~kg} /$ day $)$ compared to the ration with $1.0 \% \mathrm{DM}$ of urea $(0.215$ $\mathrm{kg} /$ day; Table 2). In this case, the ADG increase led to an increase in daily carcass production, positively affecting the RMF in the ration with $1.5 \% \mathrm{DM}$ of urea.

The NR did not show a linear or quadratic response $(\mathrm{P}>0.05)$ to the inclusion of urea in the ration, but it was higher in the rations with urea compared to the ration without urea (0.31 to $0.34 v s .0 .26 U S \$ /$ day; Table 3). This economic index increased by 24.7 , 21.6 and $34.0 \%$ in the rations with 0.5 , 1.0 and $1.5 \%$ DM of urea, respectively, in relation to the ration without urea. Vidal et al. (2004) performed an economic analysis of feedlot lambs fed rations with elephant grass hay and concentrate feed composed of ground corn + soybean meal $(50 \% \mathrm{DM})$, or the same roughage with two levels (40 and $60 \%$ DM) of two concentrate feeds composed of ground corn + soybean meal + chicken litter, and ground corn + wheat bran + urea; a higher NR was obtained with the higher level of the latter concentrate feed in the ration. Thus, the NR results reported in the present study, and by Vidal et al. (2004), demonstrate the potential of urea to reduce feeding costs and improve the profitability of lambs finishing in a feedlot.

The BCR did not show a linear or quadratic response $(\mathrm{P}>0.05)$ to the inclusion of urea in the ration (Table 3 ). All the rations presented positive BCRs, but this economic index was higher for the rations with urea compared to the ration without urea (2.05 to 2.09vs.1.74). Also, the increase from 0.5 
to $1.5 \% \mathrm{DM}$ of urea in the ration provided similar BCRs, with a mean value of 2.07. Although this increase does not represent a significant difference statistically, it is important to note that the addition of urea led to a $19.0 \%$ more economical return compared to the ration without this NPN source. These results show that all rations covered the feeding cost and supported financial gains, in which the latter was increased with the addition of urea to the ration.

The BCR values observed in the present study were similar to those found by Zundt et al. (2002), who found values ranging from 2.02 to 1.68 for rations with 12 to $24 \%$ DM of CP, respectively, which were provided to feedlot noncastrated male lambs until they reached a BW of $30 \mathrm{~kg}$; these authors observed a reduction in the BCR with an increase in the RDP content, which was associated with an increase of soybean meal content to achieve the prestablished CP content in each ration. Despite the rations used in the present study being isoproteic (17.0\% DM of $\mathrm{CP}$, on average; Table 1), the inclusion of urea increased the BCR, which reinforces the potential of this ingredient to reduce feeding costs in feedlots.

Although the addition of urea was not statistically different between the rations to enable a comparison of the $\mathrm{NR}$ and $\mathrm{BCR}$, the relative changes in these indexes led to increases of $34.0 \%$ for the NR and $17.8 \%$ for the BCR between the rations without and with $1.5 \%$ DM of urea. Thus, this level of urea addition was the nutritional approach that resulted in the best balance between the NR and BCR to support these positive variations. In the present study, the best economic result was also followed by the best biological responses (lower DMI and higher ADG and CCY; Table 2), providing even more support for the ration with $1.5 \%$ DM of urea. Also, Vivian et al. (2017) found that CP intake was not affected by the addition of urea to the rations tested in the present study, which indicates another advantage for the ration with $1.5 \% \mathrm{DM}$ of urea. Khattab et al. (2013) reported that the DM digestibility increased, the nitrogen $(\mathrm{N})$ excretion in feces is reduced and the $\mathrm{N}$ excretion in urine is not affected when the urea content increases from 0.0 to $1.5 \% \mathrm{DM}$ of ration. Thus, the addition of urea to the ration may help to reduce the damage caused by the excess $\mathrm{N}$ compounds released in the environment due to animal production.

The results reported in the present study demonstrate that finishing lambs in feedlots is economically viable, which is in accordance with other studies (Zundt et al., 2002; Vidal et al., 2004; Barroso et al., 2007), especially when urea is included in the ration (Vidal et al., 2004; Barroso et al., 2007).Regarding the ration with $1.5 \%$ $\mathrm{DM}$ of urea, the slaughter of lighter lambs (with a SW of around $32 \mathrm{~kg}$ ) may increase the economic return; in this case, the DMI is reduced (Sousa et al., 2008), the CCY may reach similar values as heavier lambs (Nascimento et al., 2018), and a large number of animals per unit of area can be finished in less time. Another aspectto be explored is the commercialization of non-carcass components, which can also increase profitability (Silva Sobrinho et al., 2005).Although statistical tools in economic analysis are of relevance to discriminate the significance of the nutritional approach, relative changes in some economic indexes, as described in this study, cannot be overlooked, especially when important decisions need to be dealt with at the farm level. 
Regarding the rations provided to the crossbred Dorper lambs in this study, levels ranging from 1.0 to $1.5 \%$ of urea, on a DM basis, are recommended for finishing lambs in feedlots due to the best balance between meat production and economic returns.

\section{ACKNOWLEDGMENTS}

The authors thank the financial support granted as a scholarship by the Coordination for the Improvement of Higher Level Personnel (Coordenação de Aperfeiçoamento de Pessoal de Nível Superior - CAPES), Brazil, Finance Code 001; and the students of CEPER of UFPR for their support in the experimental preparation and data collection during the trial.

\section{REFERENCES}

BARROS, C.S.; MONTEIRO, A.L.G.; POLI, C.H.E.C.; DITTRICH, J.R.; CANZIANI, J.R.F.; FERNANDES, M.A.M. Economic return of sheep production on pasture and feedlot. Revista Brasileira de Zootecnia,v.38, n.11, p.2270-2279, 2009.

BARROSO, D.D.; ARAÚJO, G.G.L.; HOLANDA JÚNIOR, E.V.;

GONZAGA NETO, S.; MEDINA, F.T. Bioeconomic performance of sheep in feedlot termination fed with dehydrated grapes byproducts in association with various energy sources. Revista

Ciência Agronômica,v.38, n.2, p.192198, 2007.

BURQUE, A.R.; ABDULLAH, M.; BABAR, M.E.; JAVED, K.; NAWAZ, $H$. Effect of urea feeding on feed intake and performance of male buffalo calves.
Journal of Animal and Plant

Sciences, v.18, n.1, p.1-6, 2008.

FARIA, P.B.; SILVA, J.N.;

RODRIGUES, A.Q.; TEIXEIRA, P.D.; MELO, L.Q.; COSTA, S.F.; ROCHA, M.F.M.; PEREIRA, A.A. Processing of cassava peel in sheep feeding: performance, carcass characteristics, ruminal morphology and economic efficiency. Revista Brasileira de Zootecnia, v.40, n.12, p.2929-2937, 2011.

GERASSEV, L.C.; MOREIRA, S.J.M.; ALVES, D.D.; AGUIAR, A.C.R.; MONÇÃO, F.P.; SANTOS, A.C.R.; SANTANA, C.J.L.; VIEGAS, C.R. Economic feasibility of using waste banana crop in the feeding of lambs.

Revista Brasileira de Saúde e Produção Animal, v.14, n.4, p.734744, 2013.

HOFFMANN, R.; SERRANO, O.; NEVES, E.M.; THAME, A.C.M.; ENGLER, J.J.C. Administração da empresa agrícola.6ed. São Paulo: Pioneira, 1989. 325p.

KHATTAB, I.M.; SALEM, A.Z.M.; ABDEL-WAHED, A.M.; KEWAN, K.Z. Effects of urea supplementation on nutrient digestibility, nitrogen utilisation and rumen fermentation in sheep fed diets containing dates. Livestock Science, v.155, n.2-3, p.223229, 2013.

MUSALIA, L.M.; ANANDAN, S.; SASTRY, V.R.B.; AGRAWAL, D.K. Urea-treated neem (Azadirachtia indica A. juss) seed kernel cake as a protein supplement for lambs. Small Ruminant Research, v.35, p.107-116, 2000.

NASCIMENTO, U.F.S.; SANTOS, G.R.A.; AZEVEDO, C.S.; MACEDO, 
F.A.F.; GONÇALVES, T.R.;

BOMFIM, L.E.L.M.; FARIAS, J.S.; SANTOS, A.D.F. Performance and carcass characteristics of lambs $1 / 2$

Dorper $+1 / 2$ Santa Inês, slaughtered with different thicknesses of subcutaneous fat. Revista Brasileira de Saúde e Produção Animal, v.19, n.1, p.125135, 2018.

\section{NATIONAL RESEARCH COUNCIL -} NRC. Nutrient requirements of sheep.6.ed. Washington, D.C.: National Academy Press, 1985. 99p.

PEREIRA, O.G.; SOUZA, V.G.; VALADARES FILHO, S.C.; PEREIRA, D.H.; RIBEIRO, K.G.; CECON, P.R. Intake, digestibility and performance of beef cattle receiving diets containing urea in different proportions. Ciência Animal

Brasileira, v.9, n.3, p.552-562, 2008.

ROCHA, L.P.; CARTAXO, F.Q.; SOUSA, W.H.; PIMENTA FILHO, E.C.; CUNHA, M.G.G.; VIANA, J.A.; PEREIRA FILHO, J.M. Productive and economic performance of different a genotype of lambs finished in feedlot.Revista Brasileira de Saúde e Produção Animal, v.17, n.2, p.262271, 2016.

ROZANSKI, S.; VIVIAN, D.R.; KOWALSKI, L.H.; PRADO, O.R.; FERNANDES, S.R.; SOUZA, J.C.; FREITAS, J.A. Carcass and meat traits, and non-carcass components of lambs fed ration containing increasing levels of urea. Semina: Ciências Agrárias, v.38, n.3, p.1587-1604, 2017.

SALINAS-CHAVIRA, J.; DOMÍNGUEZ-MUÑOZ, M.; BERNAL-LORENZO, R.; GARCÍACASTILLO, R.F.; ARZOLAÁLVAREZ, C. Growth performance and carcass characteristics of feedlot lambs fed diets with pig manure and rumen contents. Journal of Animal and Veterinary Advances, v.6, n.4, p.505-508, 2007.

SANTOS, J.W.; CABRAL, L.S.; ZERVOUDAKIS, J.T.; SOUZA, A.L.; ABREU, J.G.; BAUER, M.O.Soybean hulls in sheep diets. Revista Brasileira de Zootecnia, v.37, n.11, p.20492055, 2008.

STATISTICAL ANALYSIS SYSTEM - SAS. SAS user's guide: statistics. Version 9.0. Cary: SAS Institute, 2002. $513 p$.

SOARES, J.C.R.; BARCELLOS, J.O.J.; QUEIROZ FILHO, L.A.V.; OAIGEN, R.P.; CANOZZI, M.E.A.; CAMARGO, C.M.; DRUMOND, L.C.D.;

BRACCINI NETO, J.Economic evaluation of finishing beef cattle on irrigated pasture. Arquivo Brasileiro de Medicina Veterinária e Zootecnia, v.67, n.4, p.1096-1104, 2015.

SILVA SOBRINHO, A.G.; PURCHAS, R.W.; KADIM, I.T.; YAMAMOTO, S.M. Meat quality in lambs of different genotypes and ages at slaughter.

Revista Brasileira de Zootecnia,v.34, n.3, p.1070-1078, 2005.

SOUSA, W.H.; CARTAXO, F.Q.; CEZAR, M.F.; GONZAGA NETO, S.; CUNHA, M.G.G.; SANTOS, N.M. Performance and carcass traits of lambs finished in feedlot with different body conditions. Revista Brasileira de Saúde e Produção Animal, v.9, n.4, p.795-803, 2008.

SOUZA, P.P.S.; SIQUEIRA, E.R.; MAESTÁ, S.A. Weight gain, carcass traits and other body components from feedlot lambs, fed diets with different 
levels of urea. Ciência Rural, v.34, n.4, p.1185-1190, 2004.

VIDAL, M.F.; SILVA, L.A.C.; SOUSA

NETO, J.; NEIVA, J.N.M. Economic analysis of feed for sheep: urea utilization to substitute broiler litter and diets based on corn and soybeans.

Ciência Rural, v.34, n.2, p.493-498, 2004.

VIEIRA, M.M.M.; CÂNDIDO, M.J.D.; BONFIM, M.A.D.; SEVERINO, L.S.; KHAN, A.S.; SILVA, R.G.

Bioeconomical analysis of replacement of soybean meal by the meal castor for sheep in confinement. Agropecuária Científica no Semi-Árido, v.8, n.4, p.7-15, 2012.

VIVIAN, D.R.; GARCEZ NETO, A.F.; FREITAS, J.A.; FERNANDES, S.R.;

ROZANSKI, S. Performance and serum chemistry profile of lambs fed on rations with increasing levels of urea.

Semina: Ciências Agrárias, v.38, n.2, p.919-930, 2017.

ZUNDT, M.; MACEDO, F.A.F.; ASTOLPHI, J.L.L.; MEXIA, A.A.; SAKAGUTI, E.S. Performance of lambs fed with different protein levels. Revista Brasileira de Zootecnia,v.31, n.3, p.1307-1314, 2002. 


\section{Errata}

No artigo "The economic viability of the inclusion of urea in the ration for feedlot lambs", com número de DOI: 10.1590/S1519-9940200262019, publicado no periódico Revista Brasileira de Saúde e Produção Animal, vol.20 Salvador 2019, na página 1:

Onde se lia:

"The economic viability of the inclusion of ureain the ration for feedlot lambs ", Leia-se:

"The economic viability of the inclusion of urea in the ration for feedlot lambs ", 